\section{Solarization is an Effective Soil Disinfestation Technique for Strawberry Production}

\author{
T.K. Hartz ${ }^{1}$ J.E. DeVay ${ }^{2}$, and C.L. Elmore ${ }^{3}$ \\ University of California, Davis, CA 95616
}

Additional index words. Fragaria $\times$ ananassa, Verticillium dahliae, Phytophthora spp., fumigation, weed control, polyethylene mulch

\begin{abstract}
Soil solarization, alone and combined with metam sodium (MS), was evaluated as an alternative to methyl bromide and chloropicrin (MBC) fumigation, the standard soil disinfestation technique in the California strawberry (Fragaria $\times$ ananassa Duch.) industry. Tests were conducted in two consecutive annual production cycles in Irvine, Calif., an environment representative of the coastal strawberry production area. Solarization treatments were applied from late July through September for October plantings. Treatments were equally effective in reducing baited populations of Phytophthora cactorum [(Lebert and Cohn) J. Schröt] (1989-90) and P. citricola Sawada (1990-91) when compared to pathogen survival in nontreated soil. Solarization and MBC reduced Verticillium dahliae Kleb inocnlnm in 1989-90, but MBC gave superior control in 1990-91. Solarization significantly controlled annual weeds, but was less effective than MBC. In 1989-90, solarization alone increased strawberry yield $12 \%$ over the yield of nontreated plots; when combined with MS, yield increase was $29 \%$, equivalent to that achieved with MBC fumigation. Treatments were equally effective in increasing yields in the 1990-91 test. Chemical names used: sodium $N$-methyldithiocarbamate (metam sodium), chloropicrin nitrotrichloromethane (chloropicrin).
\end{abstract}

Fumigating soil with methyl bromide and chloropicrin has been an integral part of strawberry cultivation in California since about 1960 (Wilhelm and Paulus, 1980). Fumigation has minimized losses to root diseases caused by Verticillium dahliae and Phytophthora spp. and has controlled weeds sufficiently to allow the use of clear polyethylene mulch to increase crop earliness and reduce fruit rots. In California, the combination of fumigation, mulching, and drip irrigation has resulted in average yields $>40 t \cdot \mathrm{ha}^{-1}$. Recently, however, using chemical fumigants has been scrutinized increasingly by regulatory agencies; this scrutiny and the rising cost of fumigants are incentives to explore other options for controlling soil-borne pests.

A potential alternative practice is soil solarization. Solarization will control a wide range of fungal pathogens and weed pests (Katan, 1981; Katan and DeVay, 1991; Himelrick and Dozier, 1991; Pullman et al., 1981; Stapleton and DeVay, 1986). Solarization could be a particularly attractive practice for strawberry production in southern California because the crop is grown as an annual, with a summer fallow period (ideal for solarization) followed by a fall planting through

Received for publication 23 Apr. 1992. Accepted for publication 23 Oct. 1992. We gratefully acknowledge the support of the California Strawberry Advisory Board and the Kay Mukai Research Foundation. The cost of publishing this paper was defrayed in part by the payment of page charges. Under postal regulations, this paper therefore must be hereby marked advertisement solely to indicate this fact.

${ }^{1}$ Dept. of Vegetable Crops.

${ }^{2}$ Dept. of Plant Pathology.

${ }^{3}$ Dept. of Agricultural Botany. clear plastic mulch. To date, most solarization research has been conducted in areas considerably warmer than the mild marine climate of coastal southern California. This study was undertaken to document the ability of soil solarization to control annual weeds and soilborne pathogens and its effect on productivity of strawberry grown as an annual crop.

Two field studies were conducted in consecutive growing seasons at the Univ. of California South Coast Field Station in Irvine. Soil was a San Emigdio sandy loam [mixed (calcareous) thermic Typic Xerofluent]. The field was worked into raised beds on $1.7-\mathrm{m}$ centers in early July 1989 . Fertilizer was banded $10 \mathrm{~cm}$ deep at $72 \mathrm{~kg} \mathrm{~N} / \mathrm{ha}$ and $38 \mathrm{~kg} \mathrm{P} / \mathrm{ha}$. Two drip irrigation lines per bed (Turbo tape, 20cm emitter spacing; T-Systems, San Diego) were buried $5 \mathrm{~cm}$ deep. An additional drip line was buried $30 \mathrm{~cm}$ deep in the center of all beds receiving methyl bromide and chloropicrin fumigation.

Porous nylon bags containing either soil naturally infested with $V$. dahliae or soil baited with Phytophthora cactorum propagules (Juarez-Palacios et al., 1991) were buried 20 to $25 \mathrm{~cm}$ deep in plots on 13 July. Thermocouples were buried 2,10,20, and $30 \mathrm{~cm}$ deep. On 14 July, plots to be solarized were covered with $30+\mu$ m-thick, clear polyethylene mulch. All plots were then thoroughly watered through the drip lines and left undisturbed until September. During that period, soil temperatures, as monitored by thermocouple, were continuously recorded by a datalogger (model 21X; Campbell Scientific, Logan, Utah).

Soil fumigant treatments were applied from 26 Sept. to 3 Oct. All soil beds not receiving solarization treatment were mulched with clear polyethylene on 26 Sept. MBC 67/33 (67\% methyl bromide, $33 \%$ chloropicrin) was applied by delivering weighed quantities of the mixture under pressure through the $30-\mathrm{cm}$ deep drip line in the center of each treated bed; these deep drip lines functioned solely to distribute fumigant and were not part of the irrigation system. Uniform distribution of fumigant was possible due to the short plot lengths $(8 \mathrm{~m})$. Two MBC rates were evaluated: 250 or $400 \mathrm{~kg} \cdot \mathrm{ha}^{-1}$ (broadcast rate). Four metam sodium (MS) fumigant treatments were evaluated: 230 liters a.i./ha in nonsolarized beds, or 77,154 , or 230 liters $\cdot$ ha $^{-1}$ in solarized beds. All MS treatments were applied to prewetted beds (about field capacity) through constant injection in $25 \mathrm{~mm}$ of irrigation water. The packets of buried inoculum were recovered on 6 Oct. and assayed for pathogen survival by the technique of Butterfield and DeVay (1977) for V. dahliae, or JuarezPalacios et al. (1991) for P. cactorum. The design was a randomized complete block with five replications per soil fumigant or solarization treatment. After fumigant applications and immediately before planting, all polyethylene mulch was removed and replaced.

'Chandler' strawberry crowns were planted through the mulch on 19 Oct. in a four-rowper-bed configuration at a density of 100,000 plants/ha (130 plants/plot). Plants were irrigated when soil matric potential reached -25 $\mathrm{kPa}$. Preplant fertility was augmented by applying $11 \mathrm{~kg} \mathrm{~N} / \mathrm{ha}$ in irrigation water weekly from mid-November through April. Annualweed control was evaluated by weed counts taken 3 Jan. and 20 Feb. 1990. All plots were hand-weeded after each evaluation. Plots were harvested weekly from early Jan. through 21 May 1990.

A similartrial began in July 1990. The field was prepared as described. Preplant fertilizer was applied at $\left(\mathrm{kg}-\mathrm{ha}^{-1}\right) 195 \mathrm{~N}-25 \mathrm{P}-75 \mathrm{~K}$. Inoculum packets of $V$. dahliae and $P$. citricola were buried $20 \mathrm{~cm}$ deep on 20 July. Phytophthora citricola was used because a recent survey had identified it as a widespread and damaging pathogen in California strawberry fields (Mircetich, 1990). Plots to be solarized were mulched with clear polyethylene on 26 July as described. All beds were watered thoroughly.

Soil fumigation treatments were applied to mulched beds from 26 Sept. to 1 Oct. using the technique described. Treatments included MBC $67 / 33$ at 250 or $400 \mathrm{~kg} \cdot \mathrm{ha}^{-1}$ (broadcast rate) or MS at 77 liters ha $^{-1}$ in conjunction with solarization. The design was a randomized complete block with four replicates of 6-mlong plots. Inoculum packets were exhumed on 9 Oct. and assayed as described. The original solarization mulch was left in place to serve as mulch for the cropping season.

'Chandler' strawberry crowns wereplanted 16 Oct. at a density of 60,000 plants/ha. Postplant production practices were similar to those of the earlier study. Annual-weed control was determined by weed counts on 19 Nov. and 23 Jan. 1991; all plots were handweeded after each count. Plots were harvested weekly from mid-Jan. through 15 May. 
Solarization substantially increased soil temperature to a depth of at least $30 \mathrm{~cm}$ (Table 1). Temperatures developed in 1989 were higher than those in 1990 due to an earlier solarization starting date and somewhat higher insolation levels. Mean daily maximum air temperature during solarization was $28 \mathrm{C}$ in 1989 and 27C in 1990. In comparing bare soil and solarized soil temperature, note that bare soil maximums, particularly at $2 \mathrm{~cm}$, occurred after substantial drying had taken place; thermally inactivating soil pests is more effective in moist soil (Katan, 1981). The effectiveness of solarization as a pest control technique is related to time of exposure to elevated temperatures. At a 2-cm depth in solarized plots, cumulative exposure above $50 \mathrm{C}$ was $\approx 370$ and $160 \mathrm{~h}$ in 1989 and 1990, respectively. At a 20$\mathrm{cm}$ depth, cumulative exposure above $35 \mathrm{C}$ was >600 and $250 \mathrm{~h}$ in 1989 and 1990, respectively.

In the 1989-90 study, solarization, fumigation, and solarization and MS combined significantly controlled annual weeds (Table 2). Weedcontrol with MBC was superior to all solarization treatments. Hairy fleabane [ Conyza bonariensis (L.) Cronq.] was the predominant species in all treated plots, whereas nontreated plots had a mixture of fleabane and common annual-weed species, predominantly common purslane ( Portulaca oleracea L.) and annual sowthistle (Sonchus oleraceus L.). All treatments effectively reduced $P$. cactorum and $V$. dahliae inoculum.

MBC fumigation improved strawberry yield $>20 \%$ compared with nontreated plots. Solarization alone and MS fumigation alone only marginally increased yield $(P=0.10)$. However, the combination of solarization and MS, even in quantities as low as 77 liters $\cdot \mathrm{ha}^{-1}$, gave yields equivalent to those obtained with MBC fumigation.

In 1990-91, all treatments substantially controlled weeds (Table 3). MBC fumigation was again superior to solarization alone. The most prevalent weed species were common purslane, diffuse lovegrass ( Eragostis diffusa Buckl.), and Australian goosefoot ( Chenopodium pumilia $\mathrm{R}$. Br.). All solarization and fumigation treatments completely controlled $P$. citricola and reduced inoculum to undetectable levels, whereas viable propagules were easily recovered from the inoculum packets buried in nontreated beds. MBC also was highly effective against $V$. dahliae, whereas solarization was less effective but still significantly reduced inoculum. All treatments were equally effective in improving strawberry yield, pro-

Table 1. Maximum soil temperatures $\left({ }^{\circ} \mathrm{C}\right)$ during solarization.

\begin{tabular}{lllll}
\hline & \multicolumn{4}{c}{ Temp } \\
\cline { 2 - 5 } Solarization & \multicolumn{4}{c}{ Soil depth (cm) } \\
\cline { 2 - 5 }+ & 2 & 10 & 20 & 30 \\
+ & \multicolumn{2}{c}{1989} & & \\
- & 61 & 49 & 42 & 36 \\
+ & 49 & 36 & 33 & 27 \\
+ & \multicolumn{2}{c}{1990} & & \\
- & 55 & 44 & 38 & 35 \\
\hline
\end{tabular}

ductivity increased an average of $33 \%$ compared to plots receiving no soil disinfestation treatment.

Solarization controlled weeds and pathogens to a high degree, despite developing soil temperatures considerably lower than those reported from studies conducted in warmer climates. Weed populations in coastal California have a lower threshold for thermal seed inactivation than populations in the hot interior valleys (C.L.E., unpublished data). Also, the solarization period used in this study was sufficiently long to allow a cumulative exposure of several hundred hours above 50C in the top $2 \mathrm{~cm}$, the soil zone from which most annual weeds emerge.

Solarization controlled Phytophthora excellently, as it did $V$. dahliae in 1989. The less effective control of $V$. dahliae in 1990 was probably due to the lower solarization temperatures encountered. We stress that pathogen control was evaluated at a shallow depth.

Table 2. Strawberry yield and control of soil-borne pests as influenced by fumigation and solarization, $1989-90$.

\begin{tabular}{|c|c|c|c|c|}
\hline \multirow[b]{2}{*}{ Soil treatment } & \multirow[b]{2}{*}{$\begin{array}{l}\text { Weeds/plot }{ }^{y} \\
\text { (no.) }\end{array}$} & \multicolumn{2}{|c|}{ Pathogen survival (\%) } & \multirow[b]{2}{*}{$\begin{array}{c}\text { Fruit yield } \\
\left(\mathrm{kg} \cdot \mathrm{m}^{-2}\right)\end{array}$} \\
\hline & & $\begin{array}{l}\text { Phytophthora } \\
\text { cactorum }\end{array}$ & $\begin{array}{l}\text { Verticillium } \\
\text { dahliae }\end{array}$ & \\
\hline Nontreated & 62 & 100 & 100 & 4.9 \\
\hline \multicolumn{5}{|l|}{$\mathrm{MBC}^{\mathrm{x}}$} \\
\hline $250 \mathrm{~kg} \cdot \mathrm{ha} \mathbf{a}^{-1}$ & 12 & 10 & 2 & 6.3 \\
\hline $400{\mathrm{~kg} \cdot h \mathrm{a}^{-1}}^{-1}$ & 15 & 0 & 0 & 6.0 \\
\hline $\mathrm{MS}^{\mathrm{w}}, 230$ liters $\cdot \mathrm{ha}^{-1}$ & 33 & 0 & 2 & 5.4 \\
\hline Solarization & 27 & 3 & 4 & 5.5 \\
\hline+ MS, 77 liters-ha ${ }^{-1}$ & 24 & 0 & 2 & 6.3 \\
\hline + MS, 154 liters $\cdot$ ha $^{-1}$ & 20 & 0 & 0 & 6.3 \\
\hline + MS, 230 liters $\cdot h \mathrm{~h}^{-1}$ & 29 & 13 & 2 & 6.2 \\
\hline \multicolumn{5}{|l|}{ Planned comparisons } \\
\hline Nontreated vs. MBC & $* * *$ & $* * *$ & $* * *$ & $* * *$ \\
\hline vs. MS & $* * *$ & $* * *$ & *** & * \\
\hline vs. solarization & $* * *$ & $* * *$ & ** & * \\
\hline vs. solarization + MS & $* * *$ & $* *$ & ** & $* * *$ \\
\hline \multirow[t]{3}{*}{ Solarization vs. MBC } & * & NS & NS & $* *$ \\
\hline & NS & NS & NS & $* * *$ \\
\hline & ** & NS & NS & NS \\
\hline
\end{tabular}

${ }^{2}$ Expressed as percent survival in nontreated soil.

'Total of two evaluation dates.

${ }^{x} \mathrm{MBC}=$ methyl bromide and chloropicrin.

"MS = metam sodium.

Ns.,,,$+++*+$ Nonsigniticant or significant at $P=0.10,0.05$, or 0.01 , respectively.

Table 3. Strawberry yield and control of soil-borne pests as influenced by fumigation and solarization, 1990-91.

\begin{tabular}{|c|c|c|c|}
\hline Soil treatment & $\begin{array}{c}\text { Weeds/plot }{ }^{z} \\
\text { (no.) }\end{array}$ & $\begin{array}{c}\text { Verticillium } \\
\text { dahliae } \\
\text { survivaly } \\
(\%)\end{array}$ & $\begin{array}{r}\text { Fruit yield } \\
\left(\mathrm{kg} \cdot \mathrm{m}^{-2}\right)\end{array}$ \\
\hline Nontreated & 79 & 100 & 4.3 \\
\hline \multicolumn{4}{|l|}{$\mathrm{MBC}^{\mathrm{x}}$} \\
\hline $250{\mathrm{~kg} \cdot h \mathrm{~h}^{-1}}$ & 11 & 0 & 5.5 \\
\hline $400 \mathrm{~kg} \cdot \mathrm{ha}^{-1}$ & 5 & 0 & 6.3 \\
\hline Solarization & 22 & 31 & 5.6 \\
\hline$+\mathrm{MS}^{\mathrm{w}}, 77$ liters $\bullet \mathrm{ha}^{-1}$ & 11 & 15 & 5.5 \\
\hline \multicolumn{4}{|l|}{ Planned comparisons } \\
\hline Nontreated vs. MBC & $* * *$ & *** & *** \\
\hline vs. solarization & $* * *$ & ** & ** \\
\hline Solarization vs. MBC & $* *$ & $* *$ & NS \\
\hline vs. solarization + MS & NS & NS & NS \\
\hline
\end{tabular}

Due to the diminishing temperature change with solarization at increasing depth, effective control at depths $>25 \mathrm{~cm}$ is questionable, whereas chemical treatment effects canextend considerably deeper.

The impact of solarization on crop productivity was somewhat different in the two inforion was combination of solarization and MS was equivalent to MBC; in 1990-91, solarization alone was equivalent to all fumigation and combination treatments. This difference may be due, in part, to differences in cropping cest sites. The 1989-90 study was conducted on ground where strawberries had not been grown for decades, whereas the tion the previous season. Other reports diffe on solarization effects on strawberry production. Patten et al. (1989) found solarization less effective than conventional fumigation, 
while Overman et al. (1987) found solarization equally effective in increasing strawberry yields when compared to standard MBC treatment.

Row solarization and using the solarizing film as a seasonal mulch have a substantial economic advantage over conventional MBC fumigation. However, the potential savings represent a small fraction of total preharvest inputs-currently $>\$ 18,000 /$ ha-in the southem California strawberry industry. While it is clear that solarization is a useful technique for controlling soil-borne pests and improving strawberry yields, it should not be considered equivalent to $\mathrm{MBC}$ fumigation, the value of which has been documented for decades. Rather, solarization seems to be a viable alternative soil disinfestation practice that can be useful in situations for which conventional fumigant use is, or becomes, restricted.

\section{Literature Cited}

Butterfield, E.J. and J.E. DeVay. 1977. Reassessment of soil assays for Verticillium dahliae. Phytopathology 67:1073-1078.

Himelrick, D.G. and W.A. Dozier. 1991. Soil fumigation and soil solarization in strawberry production. Adv. Strawberry Production 10: 12-28.

Juarez-Palacios, C., R. Felix-Gastelum, R.J. Wakeman, E.J. Paplomatas, and J.E. DeVay. 1991. Thermal sensitivity of three species of Phytophthorua and the effect of soil solarization on their survival. Plant Dis. 75: 1160-1 164.

Katan, J. 1981. Solar heating (solarization) of soil for control of soil-borne pests. Annu. Rev. Phytopathol. 19:211-236.

Katan, J. and J.E. DeVay. 1991. Soil solarization. CRC Press, Boca Raton, Fla.

Mircetich, S.M. 1990. Soil borne disease complex in strawberry, involvement of Phytophthora spp. and Colletotrichum acutatum. Calif. Strawberry Advisory Board Annu. Rpt. p. 79-96.
Overman, A.J., C.M. Howard, and E.E. Albregts. 1987. Soil solarization for strawberries. Proc. Florida State Hort. Soc. 100:236-239.

Patten, K., E. Neuendorff, and G. Nims. 1989. Soil solarization effects on annual strawberry production in Texas. Proc. 21st Annu. Natl. Agr. Plastics Congr., Peoria, Ill. p. 71-75.

Pullman, G.S., J.E. DeVay, R.H. Garber, and A.R. Weinhold. 1981. Soil solarization: Effects on verticillium wilt of cotton and soilbome populations of Verticillium dahliae, Pythium spp., Rhizoctonia solani and Thielaviopsis basicola. Phytopathology 71:954-959.

Stapleton, J.J. and J.E. DeVay. 1986. Soil solarization: A non-chemical approach for management of plant pathogens and pests. Crop Protection 5:190-198.

Wilhelm, S. and A.O. Paulus. 1980. How soil fumigation benefits the California strawberry industry. Plant Dis. 64:264-270. 